\title{
Research Report
}

\section{Daya anti bakteri ekstrak kulit nanas (Ananas comosus) terhadap pertumbuhan bakteri Enterococcus faecalis}

\author{
Antibacterial potency of pineapple peel extract (Ananas comosus) on Enterococcus \\ faecalis growth
}

\author{
Rega Maurischa Arantika Putri ${ }^{1}$, Tamara Yuanita ${ }^{2}$ and Mohammad Roelianto ${ }^{2}$ \\ ${ }^{1 /}$ Mahasiswa Fakultas Kedokteran Gigi, Universitas Airlangga, Surabaya \\ ${ }^{2}$ Staff Departemen Konservasi Gigi, Universitas Airlangga, Surabaya
}

\begin{abstract}
Background: Root canal infections are caused by the colonization of microorganisms. Microorganisms that commonly found in root canal failure is Enterococcus faecalis. These bacteria can be found in 80-90\% of root canal infections. Currently, many plants are used as antibacterial drugs. Pineapple is one plant that can be used as antibacterial drugs. Pineapple peel has a variety of antibacterial chemical compounds, such as, bromelain, saponins, tannins and flavonoids that can inhibit the growth of Enterococcus faecalis bacteria. Aim: To obtain concentration of antibacterial from pineapple peel extract on Enterococcus faecalis growth. Methods: This study was an experimental laboratory with Post Test Only control group design using Enterococcus faecalis ATCC 29212 bacteria that were diluted based on Mc. Farland standard $1.5 \times 108 \mathrm{CFU} / \mathrm{ml}$ with pineapple peel extract treatment concentration of $100 \%, 50 \%, 25 \%, 12.5 \%, 6.25 \%, 3.125 \%, 1.56 \%, 0,78 \%$ and then planted in nutrient agar media surface evenly. Results: At concentration of 3.125\% pineapple peel extract showed that the growth of colonies was less than $90 \%$ of positive control and concentration of $6.25 \%$ pineapple peel extract had no visible Enterococcus faecalis bacteria growth as much as $99.9 \%$. Conclusion: The pineapple peel extract (Ananas comosus) have antibacterial power on the growth of Enterococcus faecalis bacterial colonies with Minimal Inhibitory Concentration (MIC) of $3.125 \%$ and the Minimum Bactericidal Concentration $(M B C)$ of $6.25 \%$.
\end{abstract}

Keywords: Pineapple peel extract (Ananas comosus); Enterococcus faecalis; Antibacterial

Korespondensi (Correspondence): Rega Maurischa Arantika Putri.; Student of Dentistry, Departement of Conservative Faculty of Dentistry, Airlangga University. Jln. Prof. Dr.Moestopo 47 Surabaya 60132, Indonesia. E-mail:

regamaurischaa@gmail.com

\section{PENDAHULUAN}

Infeksi saluran akar disebabkan oleh adanya kolonisasi mikroorganisme dan biasanya didominasi oleh bakteri anaerob. Mikroorganisme yang sering diisolasi sebelum perawatan saluran akar meliputi bakteri batang anaerob gram negatif, gram positif, coccus anaerob gram positif, gram positif anaerob dan fakultatif batang, spesies Lactobacillus, dan fakultatif gram positif seperti Streptococcus. Bakteri jenis anaerob obligat lebih mudah dihilangkan. Bakteri fakultatif seperti nonStreptococcus mutans, Enterococcus, dan Lactobacillus mampu bertahan hidup setelah dilakukan tindakan instrumentasi dan medikamen, khususnya Enterococcus faecalis yang sering diisolasi dari kasus perawatan saluran akar yang gagal. ${ }^{1}$
Enterococcus faecalis merupakan bakteri yang biasa ditemukan dalam saluran akar dan tetap bertahan di dalamnya meskipun telah dilakukan perawatan. ${ }^{2}$ Prevalensi infeksi oleh karena Enterococcus faecalis berkisar antara 24\%-77\%. Hal ini disebabkan karena berbagai faktor ketahanan dan virulensi dari Enterococcus faecalis, termasuk kemampuannya untuk berkompetisi dengan mikroorganisme lain dalam invasinya ke tubuli dentin dan kemampuannya untuk bertahan pada keadaan nutrisi yang rendah. ${ }^{3}$

Sifat resistensi bakteri Enterococcus faecalis sangat kuat, beberapa upaya telah digunakan untuk menanggulangi masalah tersebut, dan banyak alternatif yang dikhususkan untuk menghambat atau membunuh bakteri Enterococcus faecalis tersebut. Seiring berkembangnya zaman, manusia saat ini memiliki ide-ide untuk bisa menyelesaikan masalah 
tersebut. Seperti pemanfaatan bahan-bahan alami yang digunakan sebagai pengobatan, mengingat bahan-bahan kimia saat ini memiliki efek samping yang lebih jika dibandingkan dengan obat berbahan alami.

Saat ini banyak sekali pemanfaatan tumbuh-tumbuhan untuk dijadikan obat antibakteri. Salah satunya adalah penggunaan buah nanas. Buah nanas yang memiliki nama latin Ananas comosus merupakan salah satu buah tropis berasal dari Brazil yang banyak tumbuh di daerah perkebunan di Indonesia. Meskipun demikian, tidak banyak yang mengetahui tentang manfaat dari buah nanas. Apalagi kulit nanas yang ternyata banyak bermanfaat.

Buah nanas mengandung banyak gizi, seperti protein, lemak, karbohidrat, mineral, dan vitamin. Selain buahnya yang mempunyai kandungan gizi kulit nanas juga memiliki cukup gizi. ${ }^{4}$ Kulit nanas memiliki tekstur yang tidak rata dan berduri kecil pada permukaan luarnya. Kulit nanas hanya dibuang begitu saja sebagai limbah, padahal kulit nanas mengandung vitamin $\mathrm{C}$, karotenoid, antosianin, flavonoid, enzim bromelain, air, serat kasar, gula reduksi, karbohidrat, protein, dan tannin., 5,6 Enzim bromelain dapat digunakan sebagai efek antibakteri. Zat-zat dalam enzim bromelain dapat mengubah sifat fisik dan kimiawi selaput sel dan dapat menghalangi fungsi normalnya sehingga mampu menghambat dan membunuh bakteri tersebut. Senyawa lain yang terkandung dalam kulit nanas yang dapat digunakan sebagai antibakteri adalah flavonoid, saponin, dan tannin. Flavonoid merupakan senyawa fenol yang berfungsi sebagai antibakteri dan antijamur. ${ }^{7}$ Saponin dan tannin merupakan suatu senyawa alami yang banyak terdapat pada tanaman didaerah tropis dan juga bersifat antibakteri ${ }^{8}$.

Angraeni (2014) dalam penelitiannya menyebutkan bahwa KHM ekstrak kulit nanas tehadap Streptococcus mutans adalah 6,25\% sedangkan KBMnya sebesar 50\%. Jika sebelumnya sudah ada penelitian mengenai daya antibakteri ekstrak kulit nanas terhadap Streptococcus mutans, sampai saat ini belum ada penelitian mengenai kulit nanas yang mampu menghambat dan membunuh bakteri Enterococcus faecalis, maka penulis bermaksud untuk meneliti bagaimana daya antibakteri kulit nanas (Ananas comosus) terhadap pertumbuhan Enterococcus faecalis. Diharapkan manfaat kulit nanas bisa digunakan untuk menghambat dan membunuh pertumbuhan bakteri Enterococcus faecalis. Tujuan penelitian ini adalah untuk mendapatkan konsentrasi daya antibakteri ekstrak kulit nanas (Ananas comosus) terhadap pertumbuhan Enterococcus faecalis. Diharapkan dapat memberikan informasi bagaimana pengaruh ekstrak kulit nanas (Ananas comosus) pada konsentrasi tertentu terhadap pertumbuhan Enterococcus faecalis.

\section{BAHAN DAN METODE}

Penelitian ini merupakan penelitian eksperimental laboratoris, dengan rancangan Post test only control group design. Penelitian ini dilaksanakan di Laboratorium Mikrobiologi Fakultas Kedokteran Gigi Universitas Airlangga pada bulan Juli-Oktober 2015. Sampel dalam penelitian ini yaitu stok bakteri Enterococcus faecalis ATCC 29212. Besar sampel yang diperoleh menggunakan rumus Lemeshow, yaitu sebanyak 5 sampel namun dalam penelitian ini menggunakan 7 sampel agar menghasilkan data yang lebih akurat untuk masing-masing kelompok perlakuan.

Penelitian dimulai dengan pembuatan ekstrak daun kulit nanas dengan metode maserasi dengan larutan etanol 96\% yang diperoleh dari Balai Penelitian dan Konsultasi Industri Surabaya. Setelah didapatkan ekstrak kulit nanas, dilakukan persiapan bakteri Enterococcus faecalis dengan mensuspensikan dalam media BHIB sampai kekeruhan setara dengan standart 0,5 Mc Farland (1,5x $\left.10^{8} \mathrm{CFU} / \mathrm{ml}\right)$. Pembuatan formulasi ekstrak kulit nanas dengan konsentrasi $100 \%, 50 \%, 25 \%$, $12,5 \%, 6,25 \%, 3,125 \%, 1,56 \%$, dan $0,78 \%$ dilakukan dengan metode dilusi.

Penentuan KHM dan KBM dari ekstrak kulit nanas terhadap Enterococcus faecalis dimulai dari persiapan tabung sebanyak 10 tabung, 8 tabung untuk perlakuan dan 2 tabung untuk kontrol. Sebanyak $0,05 \mathrm{ml}$ suspensi bakteri yang telah distandartkan dengan 0,5 Mc Farland ditanam dalam tabung yang berisi BHIB dan ekstrak kulit nanas dengan berbagai konsentrasi. Tabung kontrol positif diisi dengan $0,05 \mathrm{ml}$ suspensi bakteri Enterococcus faecalis dan media BHIB tanpa penambahan ekstrak kulit nanas, sedangkan tabung kontrol negatif berisi media BHIB tanpa penambahan bakteri Enterococcus faecalis maupun ekstrak kulit nanas untuk memastikan bahwa tidak ada kontaminasi bakteri pada media. Setiap kelompok terdiri dari 7 sampel, kemudian seluruh tabung reaksi tersebut diinkubasi secara anaerob di anaerobic jar dalam inkubator pada suhu $37^{\circ} \mathrm{C}$ selama 24 jam. Pembacaan hasil dari ekstrak kulit nanas terhadap pertumbuhan bakteri 
Enterococcus faecalis dilakukan pengamatan jumlah koloni yang tumbuh dengan dilakukan subkultur bakteri sebanyak $0,1 \mathrm{ml}$ dari tiap tabung serta kontrol positif pada media Nutrient Agar. Penanaman pada media Nutrient Agar menggunakan metode spreader dan diinkubasi pada suhu $37^{\circ}$ selama 24 jam. Hasil yang menunjukkan penghambatan $90 \%$ pertumbuhan bakteri Enterococcus faecalis yang dibandingkan dengan kontrol positif dijadikan sebagai KHM dan yang menunjukkan kematian bakteri Enterococcus faecalis sebesar $99,9 \%$ yang dibandingkan dengan kontrol positif dijadikan sebagai KBM. KHM dan KBM ditentukan dengan cara menghitung junlah koloni yang tumbuh pada media Nutrient Agar secara manual dan dinyatakan dengan CFU/ml. Perhitungan tersebut diulang tiga kali oleh tiga pengamat yang berbeda dan diambil rata-ratanya.

\section{HASIL}

Penelitian ini bertujuan untuk mengetahui daya antibakteri ekstrak kulit nanas terhadap pertumbuhan bakteri Enterococcus faecalis secara in vitro dengan metode dilusi cair untuk menentukan kadar hambat minimal dan kadar bunuh minimal.

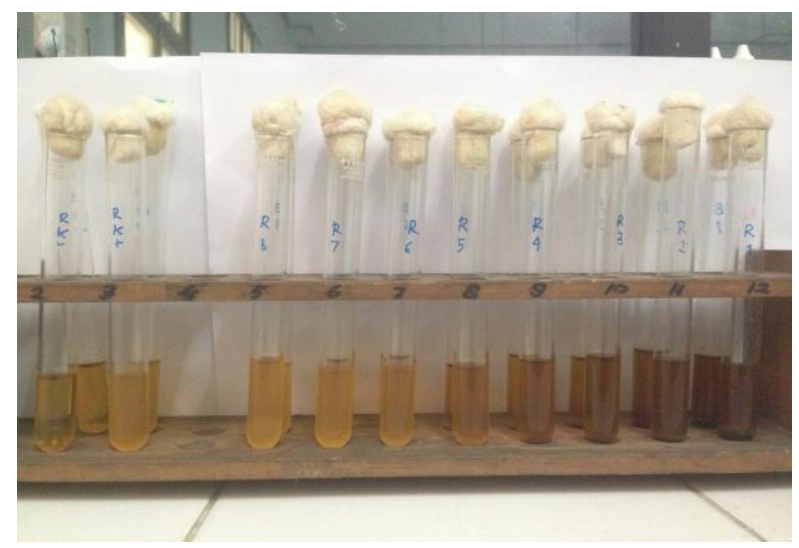

Gambar 1. Hasil uji dilusi pada konsentrasi $100 \%$, $50 \%, 25 \%, 12,5 \%, 6,25 \%, 3,125 \%, 1,56 \%$, dan $0,78 \%$, kontrol positif, dan kontrol negatif.

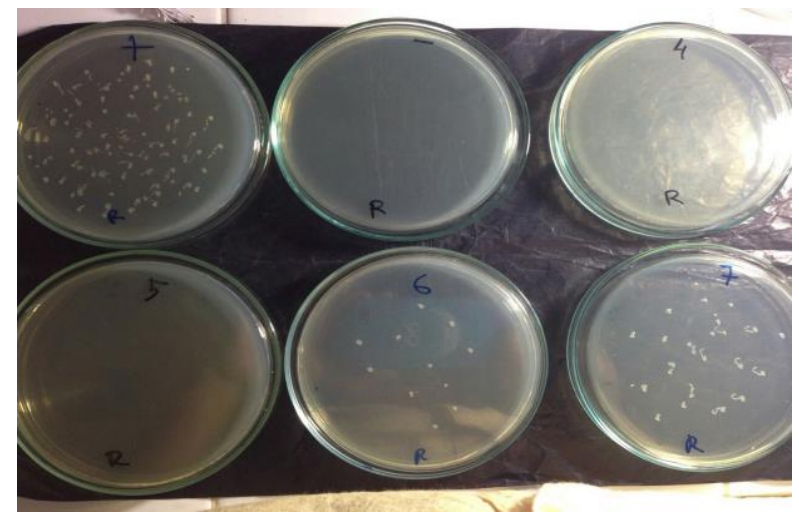

Gambar 2. Hasil pertumbuhan bakteri dari tabung kontrol positif, kontrol negatif, konsentrasi $1,56 \%$, 3,125\%, 6,25\%, 12,5\% pada media Nutrient Agar.

Hasil penghitungan jumlah koloni bakteri Enterococcus faecalis pada media nutrient agar tercantum pada Tabel 1.

Tabel 1, jumlah rata-rata pertumbuhan koloni pada media Nutrient agar dengan ekstrak kulit nanas

\begin{tabular}{lccc}
\multicolumn{1}{c}{$\begin{array}{l}\text { Kelompok } \\
\text { Perlakuan }\end{array}$} & N & $\begin{array}{c}\text { Rerata } \\
\text { jumlah } \\
\text { koloni } \\
\text { (CFU/ml) }\end{array}$ & $\begin{array}{c}\text { Rerata } \\
\text { jumlah } \\
\text { koloni (\%) }\end{array}$ \\
\hline $\begin{array}{l}\text { Konsentrasi } \\
\text { 100\% }\end{array}$ & 7 & 0 & 0 \\
$\begin{array}{l}\text { Konsentrasi } \\
\text { 50\% }\end{array}$ & 7 & 0 & 0 \\
$\begin{array}{l}\text { Konsentrasi } \\
\text { 25\% }\end{array}$ & 7 & 0 & 0 \\
$\begin{array}{l}\text { Konsentrasi } \\
\text { 12,5\% }\end{array}$ & 7 & 0 & 0 \\
$\begin{array}{l}\text { Konsentrasi } \\
\text { 6,25\% }\end{array}$ & 7 & 0 & 0 \\
$\begin{array}{l}\text { Konsentrasi } \\
\text { 3,125\% }\end{array}$ & 7 & 13,42 & 9,9 \\
\hline $\begin{array}{l}\text { Konsentrasi } \\
\text { 1,56\% }\end{array}$ & 7 & 26,14 & 19,3 \\
Konsentrasi & 7 & 0 & 0 \\
$\mathbf{0 , 7 8 \%}$ & 7 & 135,28 & 100 \\
Kontrol (+) & 7 & 0 & 0 \\
\hline Kontrol (-) & 7 & & \\
\hline & & & \\
\hline
\end{tabular}

Berdasarkan data pada tabel 1 dapat dilihat pada konsentrasi 3,125\% masih terdapat pertumbuhan kurang dari $10 \%$ maka pada konsentrasi ini disebut KHM. Pada konsentrasi $6,125 \%$ sudah tidak ditemukan adanya pertumbuhan bakteri sehingga nilai KBM diperoleh pada konsentrasi ini.

Analisis data yang pertama dilakukan adalah uji normalitas pada konsentrasi 3,125\%, $1,56 \%$, dan kontrol positif. Pada uji normalitas menggunakan uji One-Sample KolmogorovSmirnov, diperoleh hasil seperti yang tercantum pada Tabel 2 di mana semua kelompok penelitian menunjukkan nilai $\mathrm{p}>0,05$ yang artinya data berdistribusi normal. 
Tabel 2. Hasil uji normalitas

\begin{tabular}{|c|c|}
\hline Konsentrasi & $\begin{array}{c}\text { Kolmograv Smirnov } \\
\text { Test }\end{array}$ \\
\hline Kontrol Positif & $\mathrm{P}=0,791$ \\
\hline Konsentrasi 3,125\% & $\mathrm{P}=0,975$ \\
\hline Konsentrasi 1,56\% & $\mathrm{P}=0,998$ \\
\hline
\end{tabular}

Langkah selanjutnya adalah uji homogenitas varians menggunakan Levene's Test. Hasilnya diperoleh nilai $\mathrm{p}=0,035$ di mana nilai $\mathrm{p}$ $<0,05$ menunjukkan bahwa varians tidak homogen. Karena varians tidak homogen maka langkah selanjutnya untuk melihat apakah adanya signifikansi perbedaan antara ketiga kelompok perlakuan, dilakukan uji non parametrik dengan uji Kruskal-Wallis Test. Hasilnya diperoleh nilai $\mathrm{p}$ $=0,000$ di mana nilai $p<0,05$ berarti data memiliki perbedaan signifikan.

Selanjutnya dilakukan uji Mann Whitney antara kelompok konsentrasi 3,125\%, 1,56\% dan kontrol positif. Suatu nilai dianggap ada perbedaan secara bermakna jika nilai signifikansinya kurang dari 0,05. Hasilnya $\mathrm{p}=0,002$. Ini berarti menunjukkan adanya perbedaan signifikansi antar kelompok konsentrasi.

\section{PEMBAHASAN}

Mikroorganisme dipertimbangkan sebagai penyebab utama adanya kelainan pulpo-periapikal yang persisten seperti kegagalan endodontik. Spesies yang paling resisten dan paling sering ditemukan pada kasus kelainan setelah perawatan adalah Enterococcus. Enterococcus faecalis merupakan penyebab utama kegagalan perawatan saluran akar. Spesies ini merupakan bakteri fakultatif anaerob yang mudah tumbuh, cepat berkolonisasi pada tubulus dentin. ${ }^{9}$

Penelitian ini merupakan penelitian eksperimental laboratoris yang dilakukan untuk mengetahui daya antibakteri ekstrak kulit nanas (Ananas comosus) terhadap bakteri Enterococcus faecalis dengan mengetahui Konsentrasi Hambat Minimal (KHM) dan Konsentrasi Bunuh Minimal (KBM) terhadap bakteri Enterococcus faecalis. Penelitian dilakukan dengan metode dilusi dan kemudian dilakukan penghitungan jumlah koloni bakteri.
Hasil penelitian menunjukkan bahwa ekstrak kulit nanas (Ananas comosus) memiliki daya antibakteri terhadap bakteri Enterococcus faecalis, hal ini dapat ditunjukkan melalui adanya KHM dan KBM. Hasil hitung koloni menunjukkan pada konsentrasi $3,125 \%$ masih terdapat koloni pada media agar sebesar 9,9\%, hal tersebut membuktikan bahwa bakteri tidak semuanya mengalami kematian, namun sekitar 90\% bakteri hanya terhambat pertumbuhan dan proses pembentukan koloninya, sehingga sesuai dengan persyaratan konsentrasi hambat minimal yaitu mampu membunuh bakteri sekitar $90 \%$ dari total rata-rata bakteri yang berhasil tumbuh pada kontrol positif Enterococcus faecalis. ${ }^{10}$ Hal ini berarti konsentrasi hambat minimal ekstrak kulit nanas (Ananas comosus) diperoleh pada konsentrasi $3,125 \%$, sedangkan pada konsentrasi $6,25 \%$ sudah tidak didapatkan koloni, sehingga sesuai dengan persyaratan konsentrasi bunuh minimal yaitu mampu membunuh bakteri sebesar 99,9\% dari total rata-rata bakteri yang berhasil tumbuh pada kontrol positif. ${ }^{11}$ Hal ini berarti konsentrasi bunuh minimal (KBM) bahan ekstrak kulit nanas (Ananas comosus) diperoleh pada konsentrasi $6,25 \%$.

Dari hasil penelitian menunjukkan bahwa ekstrak kulit nanas (Ananas comosus) dapat bersifat sebagai antibakteri terhadap Enterococcus faecalis, hal ini dikarenakan ekstrak kulit nanas memiliki kandungan potensial seperti bromelain, flavonoid, tannin, dan saponin. Bromelain mempunyai efficacy antibakterial pada semua strain bakteri aerob maupun anaerob. Bromelain juga mempunyai sifat antiadhesi untuk mencegah perlekatan reseptor glikoprotein bakteri pada mukosa intestinal. Ini artinya bromelain mencegah perlekatan bakteri. ${ }^{12}$ Antibakterial pada flavonoid memiliki target seluler ganda. Salah satu dari molekuler tersebut membentuk ikatan kompleks dengan protein nonspesifik seperti ikatan hidrogen dan hidrofobik serta pembentukan ikatan kovalen. Sifat antimikroba dari flavonoid ditunjukkan dengan kemampuannya menonaktifkan perlekatan mikroba, enzim, protein sel transport, dan lainnya. ${ }^{13}$. Tannin dapat menyebabkan pengerutan pada dinding sel bakteri sehingga akan mengganggu permeabilitas sel dan akan menyebabkan terganggunya hidup sel, dan pertumbuhannya akan terhambat bahkan juga bisa menyebabkan kematian pada bakteri. ${ }^{14}$ Mekanisme kerja saponin sebagai antibakteri yaitu dapat menyebabkan kebocoran protein dan enzim dari dalam sel. Saponin dapat merusak permeabilitas membran. Rusaknya membran sel 
ini sangat mengganggu kelangsungan hidup bakteri. ${ }^{15}$

Uji analisis data dilakukan antar kelompok penelitian pada bakteri Enterococcus faecalis yang tumbuh pada kontrol positif, konsentrasi 3,125\%, dan konsentrasi $1,56 \%$. Analisis data pertama dilakukan uji normalitas pada masing-masing kelompok dengan menggunakan Kolmograv Smirnov untuk melihat apakah distribusinya normal, dan didapatkan p>0,05 yang berarti data berdistribusi normal. Selanjutnya dilakukan uji homogenitas dengan Levene Test dan didapatkan nilai $\mathrm{p}<0,05$ yang berarti data pada penelitian ini tidak homogen. Maka untuk melihat adanya signifikansi perbedaan antar kelompok perlakuan menggunakan uji non parametrik Kruskal-Wallis Test. Pada uji Kruskal-Wallis Test ini didapatkan hasil $\mathrm{p}=0,000(\mathrm{p}<0,05)$ yang menunjukkan bahwa ada perbedaan yang signifikan antar kelompok konsentrasi. Selanjutnya dilakukan uji Mann Whitney Test untuk mengetahui apakah ada perbedaan yang signifikan antara masing-masing kelompok konsentrasi.

Berdasarkan hasil dan pembahasan dalam penelitian ini, dapat ditarik kesimpulan bahwa ekstrak kulit nanas (Ananas comosus) mempunyai daya antibakteri pada konsentrasi 3,125\% sebagai Konsentrasi Hambat Minimal (KHM) dan konsentrasi 6,25\% sebagai Konsentrasi Bunuh Minimal (KBM) terhadap Enterococcus faecalis.

\section{DAFTAR PUSTAKA}

1. Jaju S, Jaju PP. 2011. Newer Root Canal Irrigants in Horizon: a Review. International Journal of Dentistry, Vol. 2011, pp 1-2.

2. Nurdin D, Satari MH, 2013. Peranan Enteroccocus faecalis Terhadap Persistensi Infeksi Saluran Akar. Konservasi Gigi dan Biologi Oral. Universitas Padjajaran. p. 4. Available from http://pustaka.unpad.ac.id/wpcontent/uploads/2013/06/peranan_enterococcus faecalis2.pdf. Accessed on March 20, 2015.

3. Santoso ML, Sudirman A, Setyowati L. 2012. Konsentrasi hambat minimum larutan propolis terhadap bakteri Enterococcus faecalis. Jurnal PDGI, 61 (3), p. 97.

4. Kumaunang M, Kamu F. 2011. Aktivitas Enzim Bromelin dari Ekstrak Kulit Nenas (Anenas Comosus). Jurnal Ilmiah Sains, 11 (2), p. 198.

5. Erukairune OL, Ajiboye JA, Adejobi RO, Okafor OY, Adenekan SO. 2011. Protective
Effect of Pineapple (Ananas comosus) Peel Extract on Alcohol-Induced Oxidative Stress in Brain Tissues of Male Albino Rats Asian Pac. J. Trop. Disease. Asian Pacific Journal of Tropical Disease, p. 5.

6. Damogalad V, Edy HJ, Supritati HS. 2013. Formulasi Krim Tabir Surya Ekstrak Kulit Nanas (Ananas comosus L Merr) dan Uji In Vitro Nilai Sun Protecting Factor (SPF). Jurnal Ilmiah Farmasi, 2 (2), p. 39.

7. Angraeni DP, Rahmawati AD. 2014. Efektivitas daya antibakteri ekstrak kulit Nanas (ananas comosus) terhadap pertumbuhan Streptococcus mutans. Karya Tulis Ilmiah Universitas Muhammadiyah Yogyakarta, Pp 3-5.

8. Wahyuni IMD, Muktiani A, Christiyanto M. 2014. Kecernaan Bahan Kering dan Bahan Organik dan Degradabilitas Serat pada Pakan yang Disuplementasi Tanin dan Saponin. Agripet, 14 (2), pp. 115-124.

9. Wardhana DV, Rukmo M, Budi AT. 2008. Daya Antibakteri Kombinasi Metronidazol, Siproflosaksin, dan Minosiklin terhadap Enterococcus faecalis. Jurnal Imu Konservasi Gigi, 1 (1), pp. 23-28.

10.Duskova M, Karpiskova R. 2013. Antimicrobial Resistance of Lactobacilli Isolated from Food. Czesh J Food Sci, 31 (1), p. 28.

11.Forbes, A Berty. 2007. Bailey and Scott's Diagnostic Microbiology, $12^{\text {th }}$ ed. St. Louis: Mosby

12.Praveen NC, Rajesh A, Madan M, Chaurasia VR, Hiremath NV, Sharma AM. 2014. In Vitro Evaluation of Antibacterial Efficacy of Pineapple Extract (Bromelain) on Periodontal Pathogens. Journal of International Oral Health, 6 (5), pp. 96-98.

13. Kumar S, Pandey AK. 2013. Chemistry and Biological Activities of Flavonoids: An Overview. Hindawi Publishing Corporation The Scientific World Journal, Vol. 2013: 16.

14.Juliantina, FR. 2009. Manfaat Sirih Merah (Piper crocatum) Sebagai Agen Anti Bakterial Terhadap Bakteri Gram Positif dan Gram Negatif. JKKI-Jurnal Kedokteran dan Kesehatan Indonesia, 1 (1), p. 2.

15.Rijayanti RP, Luliana S, Trianto HF. 2014. Uji Aktivitas Antibakteri Ekstrak Etanol Daun Mangga Bacang (Mangifera foetida L.) Terhadap Staphylococcus aureus Secara In Vitro. Fakultas Kedokteran Universitas Tanjungpura, 1 (1), pp. 12-13. 